\title{
THE APPLICATION OF MICROCONTROLLER BASED SYSTEM TO DESIGN OF ELECTRO MECHANICAL MANIPULATOR STICK
}

\author{
Mei Edi Prayitno ${ }^{1}$, Aab Abdul Wahab ${ }^{2}$, Muhammad Zulkifli ${ }^{3}$ \\ 1,2,3 Indonesian Naval Technology College, \\ STTAL-Bumimoro-Morokrembangan, Surabaya 60187, Indonesia
}

\begin{abstract}
Independence and advancement of defense equipment in our country demands the professional and high dedication of TNI soldiers, especially the Navy. A soldier must be able and master, operate, and maintain and can solve any problems arising either due to usage or due to technical errors that occur on defense equipment both in operation and hombase. In practice grenade throwing on the field are often found unexploded grenades after being thrown. At this time the handling of unexploded grenades is detonated on the spot, however the tool used to locate the crushing explosives is still very traditional by using bamboo poles. In this final project there will be a tool for placing crushing explosives on unexploded grenade handling procedures in the field, using a long, folded, robotic arm stick that is driven by a gearbox motor, the mechanism of this tool will be made with the arm system using Electromechanical systems. At the end of the stick is installed gripper which serves to clamp the explosives before being placed on unexploded grenades. Stick Manipulator to be created can assist trainers and instructors in the implementation of explosive placement on unexploded grenade handling procedures on target and can be an additional tool of equipment owned by current trainers and instructors and can be useful for units in need, And held a grenade throwing exercise.
\end{abstract}

Keywords: Grenade, Galah / Bamboo, Stick Manipulator.

\section{INTRODUCTIONS}

The independence and progress of defense equipment in our country demands high professionalism and dedication from all TNI soldiers, especially the Navy. A soldier must be able and master, operate, care for and maintain and be able to overcome any problems that arise both as a result of use and due to technical errors that occur in the defense equipment both in the operation and hombase. Mastery of weapon material is absolute for all soldiers, individual weapons themselves, there are several kinds ranging from assault rifles, grenade launchers, hand grenades, bayonets and so on. Grenades are individual weapons, namely group killer weapons made of explosives wrapped in cladding equipped with igniters and detonators, operating by throwing them.
At present the handling of grenades that do not explode is by being exploded on the spot, however the tools used to place the explosive destroyers are still very traditional, namely by using a pole from bamboo. In principle, bamboo can be used as a medium to place explosives that have been strung together with detonators next to or above unexploded grenades, but bamboo still has some deficiencies, among others, the nature of bamboo which is flexible so that the explosive placement is not right on target, easily broken , can't see objects at certain distances, touch technology is lacking, very simple. Another alternative is to use explosive tamer robots but the terrain constraints are very influential on robot mobility on the ground because the grenade throwing area is steep and steep.. 
While this paper will be made a tool to place the explosive destroyer on the procedure of handling grenades that do not explode in the field, using a long stick robot arm that can be folded and driven using a gearbox motor, the mechanism of this tool will be made using the arm system using electromechanical system. At the end of the stick a gripper is installed which serves to clamp explosives before being placed on an unexploded grenade, also mounted a camera on the gripper to see the position of the unexploded grenade that the operator can see on the LCD monitor mounted on the body of the tool. The control center of this device is an Arduino microcontroller that is connected to a motor driver to drive the motor. This concept was created as an innovation and development of existing tools such as the tools discussed above. So that soldiers or trainers throw grenades can secure grenades by putting destructive explosives at a radius far enough from the range of grenade explosions without direct contact with grenades, with this tool also more precise because there is no movement or vibration that occurs on the stick as happened in bamboo pole tool.

The Stick Manipulator that will be created can help trainers and instructors in carrying out explosives placement on procedures for handling grenades that do not explode precisely on target and can be additional equipment tools for trainers and instructors at this time and can be useful for units in need, and hold grenade throwing exercises.

The results of the stick manipulator design can be developed in the future for field applications in terms of facilitating the trainer in implementing procedures for handling unexploded grenades (edema).

\section{MATERIAL/METHODOLOGY}

In this paper, in this case the microcontroller-based arm manipulator with an electromechanical system, needs to be supported by the existence of basic theories related to electronics and mechanics. In making the tools must be taken into account the selection of materials, the selection of motors, and the forces acting on these tools as well as other components that support their work. The tools are obtained from reference books, so that the arm manipulator based on microcontrollers with electromechanical systems can function properly.

\subsection{Research Methodology}

This type of research is research and development where in this study was carried out with the aim of making new innovations with tools that have been made to get more value and carry out further development.

The method used in the preparation of this thesis has several parts, namely as follows: a. Background.

Analyze the data in the field why and for what this tool is made and used.

b. Problem Statement.

Planning the making of mechanical and electrical mechanical systems by studying existing data and by calculating to obtain the right results in planning..

c. Literatur Review.

Studying theoretical theories and supporting data for the writing process obtained from literature, journals, articles on the internet that support calculations and formulas for writing paper approaches. 


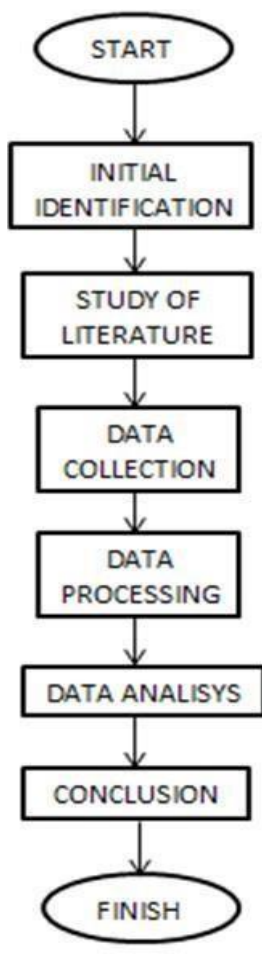

Figure 1. Research Flow Chart

\subsection{Research design}

The design of this research can be explained in Figure 1. Flowchart describes the process of conducting research in the final assignment from the beginning of the work until the completion of the final assignment research. The work starts from identifying problems that are the topic determinants to be appointed for the writing of this study. In this study the author wanted to raise the topic of a tool that is shaped like a stick with the mechanism of a robotic arm that can be elongated which is used to place a non-explosive grenade destroyer. As for the block diagram of the design in this study can be seen in Figure 2 below.

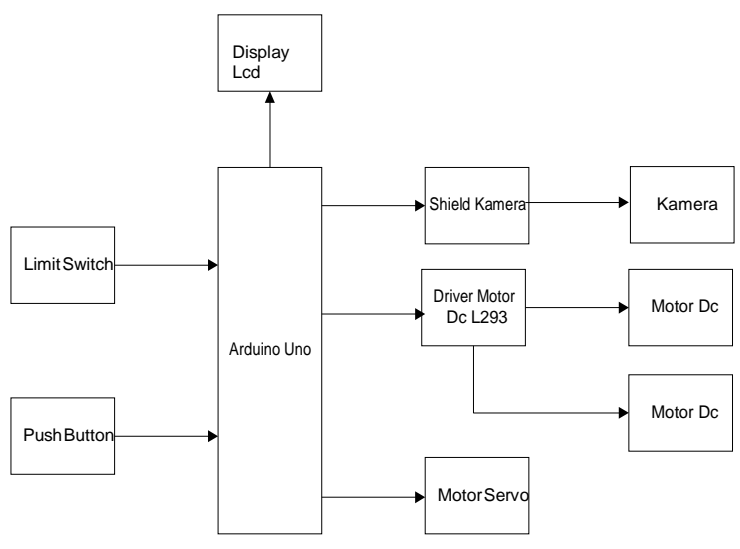

Figure 2. Block diagram

\section{RESULT AND DISCUSSION}

\subsection{System planning}

System design consisting of hardware design and software design. The design of hardware (hardware) aims to realize the idea of becoming an electronic circuit consisting of several sub-systems. While the design of software aims to support the work of hardware in order to enable the hardware to function as planned so that it can work.

\subsection{Designed tool scheme}

This scheme is made with the intention to facilitate the placement of mechanical components that drive the stick manipulator, besides that it is also used as a reference for system calculations. This scheme also aims to get a complete picture of the complete stick manipulator electromechanical system. The tool scheme can be seen in Figure 3

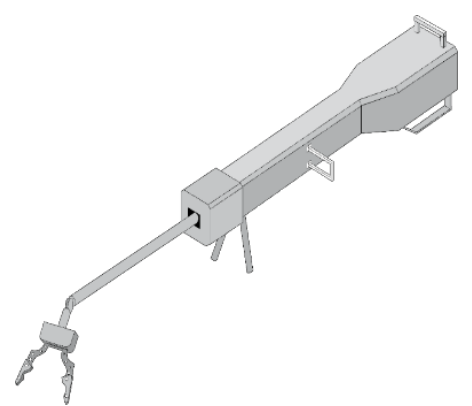

Figure 3. Design of the Manipulator Stick 


\subsection{Calculate the force to be lifted}

In calculating the load, the variables that are in the load must be sought, namely heavy, there are two tools or main components of the load, namely explosives (TNT) and Tripot / buffer. To be able to destroy unexploded grenades, at least twice the weight of the blast will be needed, so if the overall grenade weight is 200 $\mathrm{gr}$ then the destroyer explosive is needed:

Load weight $=200 \mathrm{gr}$

Explosives needed $=2 \times 200 \mathrm{gr}=400 \mathrm{gr}$

Next, calculate the weight of the supporting plate, namely;

The support plate is made of strip plate with a length of $400 \mathrm{~mm}$, width of $20 \mathrm{~mm}$ and thickness of $2 \mathrm{~mm}$.

So;

$$
\begin{gathered}
V=p \times I \times t \\
=0,4 \times 0,02 \times 0,002 \\
=0,000016 \mathrm{~m} 3 \\
=0,016 \mathrm{dm} 3
\end{gathered}
$$

To get the weight, you must first find the specific gravity of iron, the specific gravity of iron is 7.85 , then:

$$
\begin{aligned}
& W=S \times V \\
& =7,85 \times 0,016 \\
& =0,125 \mathrm{~kg}
\end{aligned}
$$

The buffer plate has 2 finished parts

$=0,125 \times 2=0,251 \mathrm{Kg}$

Weight $=$ Specific gravity $\times$ Volume

Load weight $(\mathrm{Kg})=$ Berat Jenis $\times$ Volume $(\mathrm{dm} 3)$

The total load calculation that works on the gripper is:

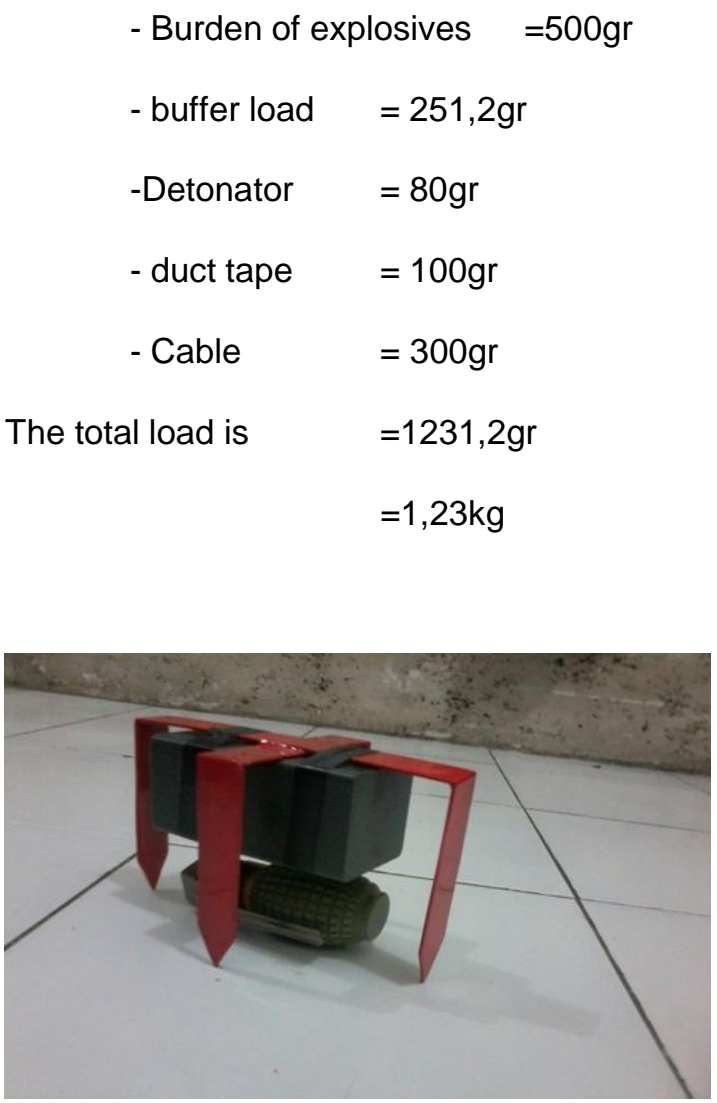

Figure 4. Buffers that have been made

\subsection{Perancangan gripper/penjepit}

One of the main components is a gripper where the gripper is an actuator in executing the object to be moved, the gripper design as shown in figure 5 .
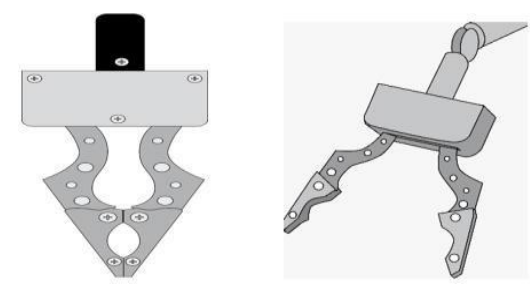

Figure 5. Gripper Design

\subsection{Look for gripping forces on gripper.}

The tangential load on the lever arm can be used to determine the amount of gripping force on the gripper, the rotation of the last gear can be used by the gripper in clamping ie by 
comparison of distance.

$\mathrm{Fa} \times \mathrm{L}=\mathrm{WT} \times \mathrm{Fa} \times 200 \mathrm{~mm}=\mathrm{WT} \times 20 \mathrm{~mm}$ Looking for tangential loads (WT) $\mathrm{WT}=\frac{\square}{\square} \mathrm{Q}[\ldots \ldots \ldots \ldots . . . .($ Khurmi 2002)

Looking for power on the motor to move the gripper. The motor used is 9 Volts if the current $(I)=0.8$ Ampere (measured). Then motor power can be searched by equation:

$$
\begin{aligned}
& P=V x I \\
& =12 \times 0,6 \\
& =7,2 \text { Watt }
\end{aligned}
$$

$\square=\frac{2 \square . \square . \square}{60}$ where $r=20 \mathrm{~mm}=0,02 \mathrm{~m}$

$$
\square=\frac{3,14 \cdot 0,02 \cdot 116}{60}
$$

$=0,024 \mathrm{~m} / \mathrm{s}$

$$
\text { Cs }=0,8 \text { (R.S. Khurmi) } \rightarrow \text { assumed to }
$$

work with a stedy for 3 hours / day.

$$
\begin{gathered}
\mathrm{WT}=\frac{\square}{\square} \square \square \\
\mathrm{WT}=\frac{7,2 \square \square \square \square}{0,024 \square / \square .0,8} \\
=240 \mathrm{~N}
\end{gathered}
$$

So, $\quad F a . L=W T . X$

$$
\begin{aligned}
\mathrm{Fa}= & \frac{\mathrm{WT} \cdot \times}{\square} \quad \mathrm{Fa}=\frac{240 \square \cdot \square \square}{250 \square \square} 20 \\
= & 19,2 \mathrm{~N} \\
& =1,959 \mathrm{~kg}
\end{aligned}
$$

So gripper strength grips and lifts maximum objects weighing 1959 grams.

Look for gripping forces on the gripper so that objects do not fall lifting 1200 grams of objects as shown in Figure 9. .

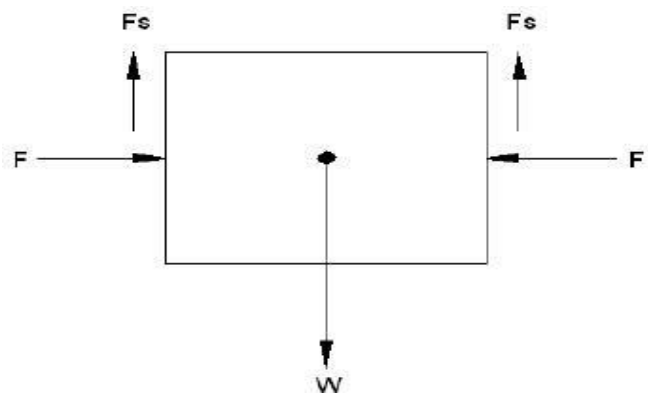

Figure 6. Gripper Gripping Style

Gripping style:

$$
\begin{aligned}
& \Sigma \mathrm{Fx}=0 \\
& \Sigma \mathrm{Fy}=0 \\
& \mathrm{~W}=2 . \mathrm{Fs} \\
& \mathrm{W}=2 . \mu \mathrm{s} . \mathrm{F}
\end{aligned}
$$

Look for the coefficient of friction $(\mu \mathrm{s})$ (Binsar, "Mechanical Mechanics") as shown in figure 10

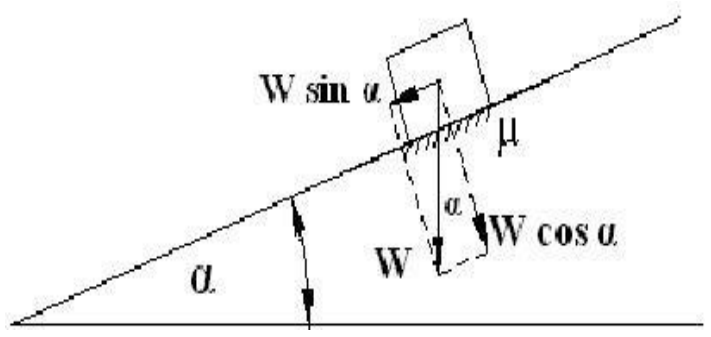

Figure 7 Swipe Coefficient

Known angle $\alpha=20^{\circ}$

$W \sin \alpha W \cos \alpha \cdot \mu s=0$

$$
\begin{aligned}
& \mu \mathrm{s} \cdot \cos \alpha=\sin \alpha
\end{aligned}
$$

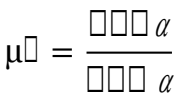

$$
\begin{aligned}
& \mu \mathrm{s}=\operatorname{tg} \alpha \\
& \mu \mathrm{s}=\operatorname{tg} 20^{\circ} \\
& \mu \mathrm{s}=0,36 \\
& \square \square=\frac{\square}{2 \cdot \mu \square}=\frac{1200 \square \square}{2 \cdot 0,36}
\end{aligned}
$$




$$
\begin{aligned}
& =1666,6 \mathrm{gr} \\
& =16,33 \mathrm{~N}
\end{aligned}
$$

So the gripping style needed by the liner to reach 1200 grams is

$\mathrm{FS}=16,33 \mathrm{~N}$

$\mathrm{Fa}$ is the gripping force on the gripper

amounting to $1959 \mathrm{gr}$

Known: 1 gram $=0,00980665 \mathrm{~N}$

So : $1959 \mathrm{gr}=19,198 \mathrm{~N}$

Fa $>$ FLoad.

So it's safe that things don't fall.

The power needed to grip 1200 grams of object; $\mathrm{P}=\mathrm{F}$. v....(Halliday, " Physics") Where , F = gripping Force $(\mathrm{N})$

$\mathrm{v}=$ clamping speed $(\mathrm{m} / \mathrm{s})$

$\mathrm{P}=\mathrm{F}$

$$
=16,33 \mathrm{~N} \cdot 0,024 \mathrm{~m} / \mathrm{s}=0,391
$$

Watt

Then the current needed to lift the load is 1200 grams, which is equal to ;

$$
\begin{aligned}
I & =\frac{\square}{\square} \\
& =\frac{0,391}{12} \\
& =0,032 \text { Ampere }
\end{aligned}
$$

\subsection{Calculation of stick drive motor}

The calculation of the power on the stick drive motor starts from the total $F$ that works on the gripper and on the motor connection. Then the calculation continues on the calculation of the motor speed opening and closing the stick and the moment that occurs on the stickmanipulator. according to the needs of the tool.
Next is calculating the force acting on the stick, if it is known that :

$$
\mathrm{F} \text { total }=\mathrm{F} \text { Load }(\mathrm{F} 1)+\mathrm{F} \text { gripper }(\mathrm{F} 2)
$$

$+\mathrm{F}$ servo motor connection (F3)

$$
\begin{aligned}
\text { Then } ;= & \mathrm{F} 1+\mathrm{F} 2+\mathrm{F} 3 \\
& =(1,2 \times 9,81)+(0,8 \times 9,81)+(0,3 \times \\
& 9,81)+(0,2 \times 9,81) \\
= & 11,772+7,84+2,943+1,962 \\
= & 24,517 \mathrm{Kgf}
\end{aligned}
$$

For the security factor, $50 \%$ is added from the results of the calculation of force so;

$$
\begin{aligned}
& =24,517+(50 \% \times 24,517) \\
& =36,775 \mathrm{Kgf}
\end{aligned}
$$

From the calculation of the force above, it can be known that torque moment that occurs on motor 2 is;

$$
\begin{aligned}
\square= & F \times I \\
& =36,775 \mathrm{Kgf} \times 1,6 \mathrm{~m} \\
& =58,84 \text { N.m }
\end{aligned}
$$

Calculation of motor power needed to move the stick. The motor used is $12 \mathrm{~V}$ as shown in figure 11.

$$
P=F x v
$$

Then ;

$$
\begin{aligned}
& =F \times(\square \square \square \square \square) / 60 \\
& =58,84 \times(3,14 \times 0,02 \times 95) / 60 \\
& =5,825 \mathrm{~W}
\end{aligned}
$$

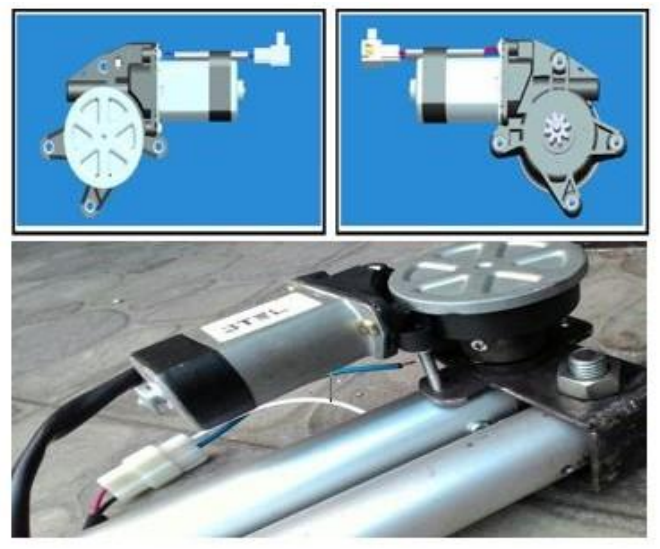

Figure 8. Drive DC motor 


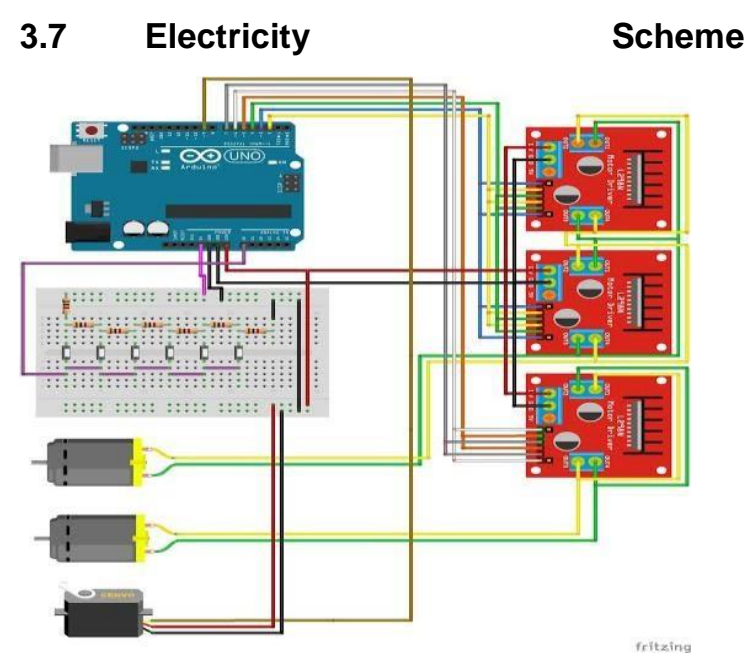

Figure 9. Electricity Installation Scheme

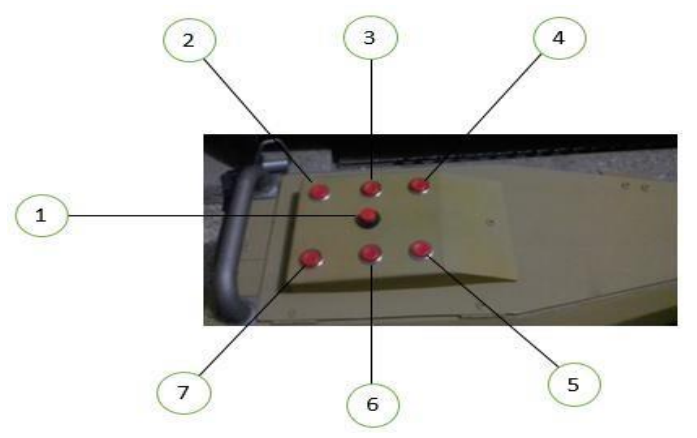

Figure 10. Push button panel

Description of the push button button:

1. Camera

2. Open stick drive motor

3. Closed stick drive motor

4. Open gripper drive motor

5. Closed gripper drive motor

6. Servo motor up

7. Down servo motor

\subsection{Choosing a Battery as a Power Source}

Batterey or battery in this system is a power source. In choosing batteries it must be adjusted to the needs needed in the circuit, before we choose the batterey we first calculate the current load that must be borne by the system to supply electric current to each motor. Known:
DC Motor $=2$ buah

Servo motor $=1$ buah

$$
\text { Then : } \quad \begin{aligned}
\text { I total } & =11+12+13 \\
& =0,6+0,8+7,2 \\
& =8,6 \mathrm{~A} \\
& =9 \mathrm{~A}
\end{aligned}
$$

So the three motors require a current supply of $7 \mathrm{~A} / 12 \mathrm{Vc}$. For batterey that will be used is batterey motorbike, in the market batterey motorbike for its current capacity is $3.5 \mathrm{Ah} / 12 \mathrm{Vdc}, 6 \mathrm{Ah} / 12 \mathrm{Vdc}$ and $9 \mathrm{Ah} / 2 \mathrm{vdc}$. The capacity of a car / motorcycle battery is stated in "Ampere Hour" or abbreviated as "Ah". The magnitude shows how much current (I) electricity can be supplied by a battery for 1 hour of use. Example; A battery with a $12 \mathrm{~V}$ 3.5Ah capacity can produce 3.5 amperes of electric current for 1 hour, or 7 amperes for 30 minutes, and 210 amperes for 1 minute, and 12.6 kilo amperes for 1 second.

For batteries that will be used are batteries with a capacity of $9 \mathrm{Ah} / 12 \mathrm{Vdc}$ for motor life in this system. As in figure 4.13. The calculation is as follows:

Known :

$$
\begin{aligned}
& \text { Accu }=9 \mathrm{Ah} / 12 \mathrm{Vdc} \\
& \text { I needed }=9 \mathrm{~A} / 12 \mathrm{Vdc}
\end{aligned}
$$

Then the capacity of the battery can be used for:

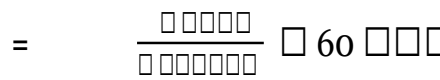

$$
\begin{aligned}
& =\quad \frac{9}{8,6} \square 60 \square \square \square \\
& =\quad 65,9 \mathrm{mnt}
\end{aligned}
$$

Accu with a capacity of $9 \mathrm{Ah} / 12 \mathrm{Vdc}$ can be used to turn on 3 units of motor 65.9 minutes continuously.. 


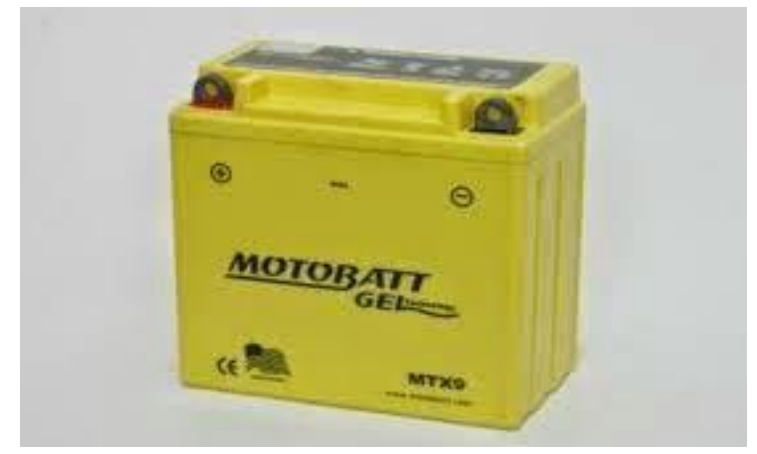

Figure 11. Batterey with a capacity of $9 \mathrm{Ah} /$

$12 \mathrm{Vc}$

The design of the stick manipulator tool that has been made will then undergo a testing process, whether it has been running as expected or not. As shown in figure 13.

Then do the testing step:

\section{a. Gripper}

1. Gripper tested using the gripper button, whether the gripper jaw can move open and close. Then also tested whether the gripper can move softly as expected.

2. Gripper tested by clamping / holding a box or round object that has dimensions in accordance with the motor specifications on the gripper.

3. Can the gripper move gently.

4. Gripper tested to hold grenades or other similar round objects.

5. The servo motor is tested to find out whether the motor is able to rotate the shaft to move the gripper up and down.

b. Manipulator arm

1. test the manipulator arm while testing the existing electrical system so that it is a unit, whether the electrical system can provide energy to the motor so the system can work..

2. Test the motor whether it is able to lift the given load.

3. Testing the camera and monitor whether it is connected properly.

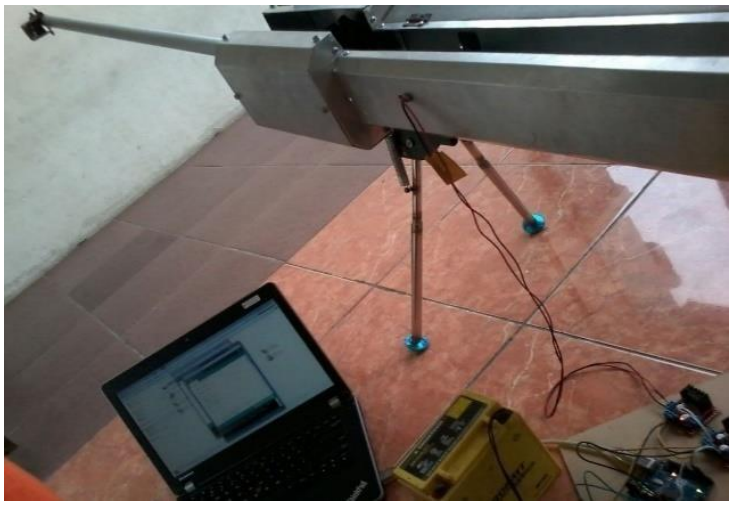

Figure 12. System testing

a. Overall system testing

In testing systems and tools as a whole is the process of turning on the system to run the main motor drive up to the gripper that is able to clamp and move objects to work from the camera and monitor to the maximum. Testing using tools and materials in accordance with real conditions in the field.

Tests are carried out to find out how the tools we make work, so we can know the strengths and weaknesses of the tools. As shown in Figure 15. The obstacles that arise will later become corrective material for improvement and to improve the quality and design of a better tool. 

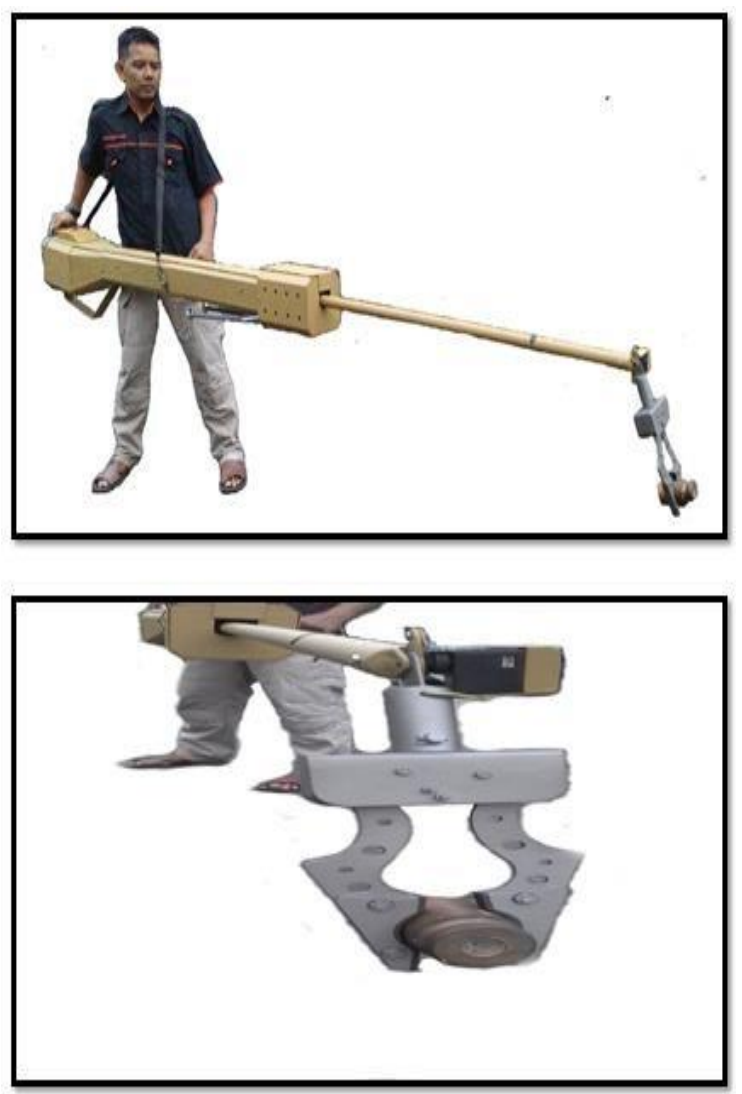

Figure 13. Testing of stick manipulator tools

In testing the tool as a whole it was found that the stick manipulator was able to work according to the calculations performed. The stick is able to lift a maximum load of $2 \mathrm{~kg}$ or is able to work lifting weights with a style of $19.62 \mathrm{Kgf}$. Whereas only $1.2 \mathrm{Kg}$ or $11,772 \mathrm{Kgf}$ is needed.

\subsection{Design of Mechanical Devices}

The construction of a mechanical system is guided by the design plan specified in a technical drawing, in accordance with the design. As shown in Figure 16. However there was a slight change with the stick whose initial design was $4500 \mathrm{~mm}$ shortened to $3800 \mathrm{~mm}$ because in addition to the large force moments we referred to the literature there was an average of only 12 feet or about $3600 \mathrm{~mm}$.

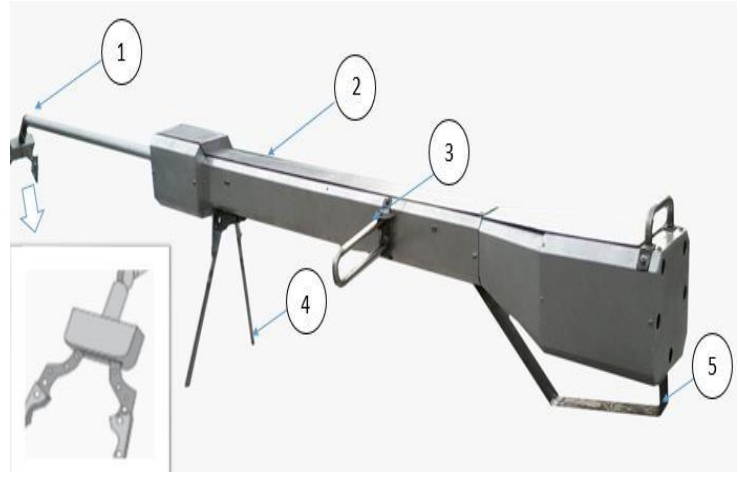

Figure 14. Design of a Mechanical Device.

Caption:

\begin{tabular}{|l|l|}
\hline NO & \multicolumn{1}{|c|}{ Caption } \\
\hline 1 & Gripper Unit \\
\hline 2 & manipulator Housing stick \\
\hline 3 & Brace \\
\hline 4 & Front Buffer \\
\hline 5 & Rear Buffer \\
\hline
\end{tabular}

\subsubsection{Gripper Unit}

The stick manipulator component which plays an important role is a gripper unit, which functions as an actuator from a stick manipulator. Therefore the gripper design must be strong, lightweight, so that it can be operated optimally. A sleek design will also affect the gripper's work in addition to aesthetic values

\subsubsection{Mechanical Arrangement of Gripper Drive}

Gripper movement patterns that can be produced vary according to the shape of the workpiece. These movements are influenced by the mechanical arrangement of each driving link that is driven by a DC motor drive. The installation of a DC motor to the main driving gear is connected to a worm gear.

To move the two main driving gears on the left and right gripper jaws are connected to 
the worm gear. Thus the left and right main propulsion gear can move symmetrically in making the gear mechanics undergo a slight change from the initial design plan, because the resulting movement is not stable due to the material used is not in accordance with the load acting on the gear. Figure 17 is the starting of the gears while the new gears are shown in Figure 18.

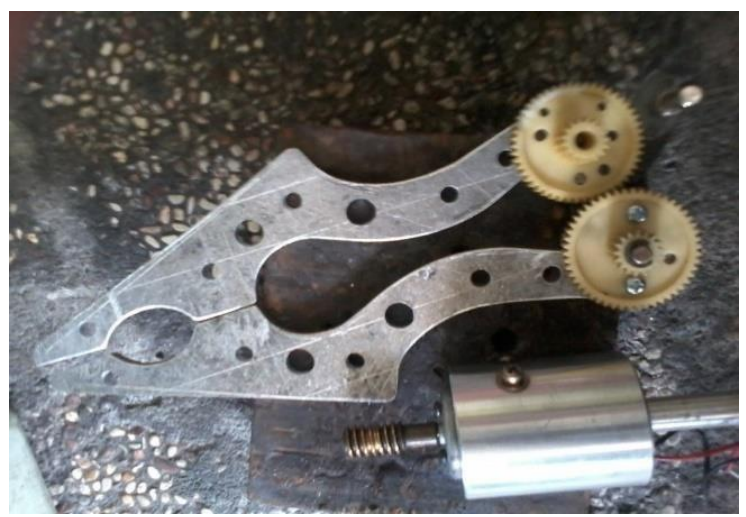

Figure 15. The old gripper driving mechanism

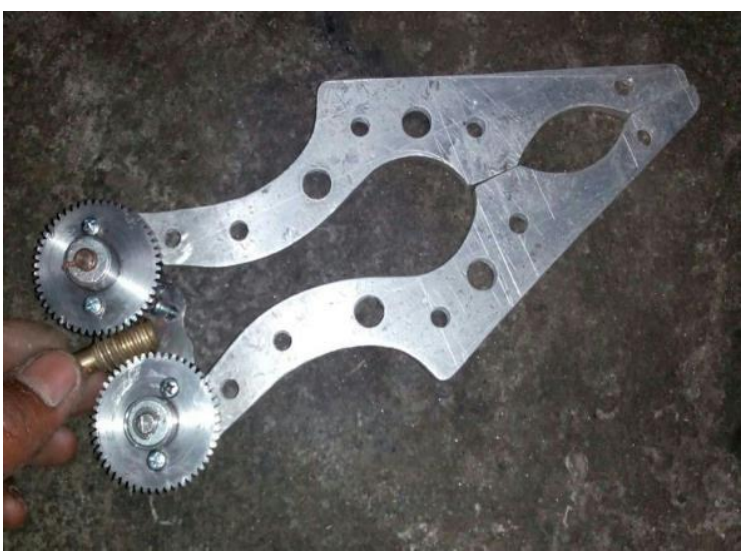

Figure 16. The new gripper driving mechanism

\subsubsection{Gripper Work Results}

When the gripper unit is closed, as in

Figure 17.

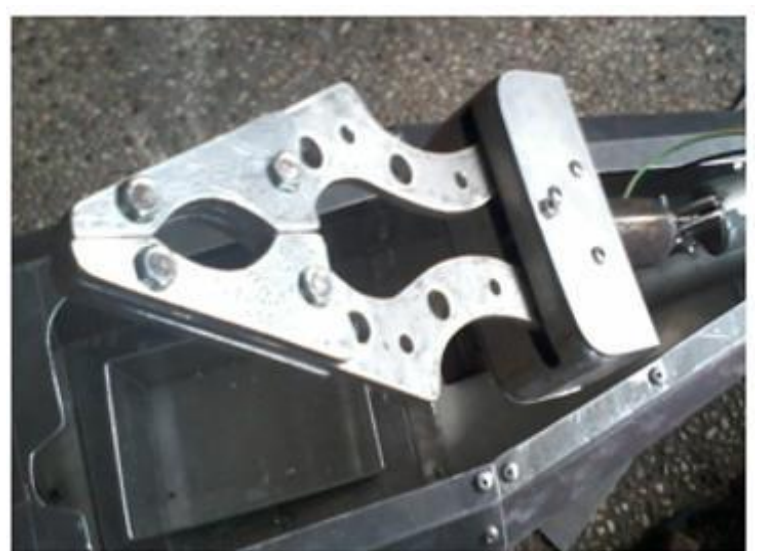

Figure 17. Gripper when closing

When the CCW motor moves, the worm gear will rotate to the left, so it will move the gear and jaw inward because the gripper's jaws and gear become a single unit tied to the bolt the number of bolts is 2. When the gripper is closed the maximum is shown in the picture above, the gripper jaw can close the meeting, when the gripper closes the maximum it will of course differ in dimensions when the gripper is in a fully opened state. The gripper dimension when closing maximally is $250 \mathrm{~mm}$ long and $120 \mathrm{~mm}$ wide.

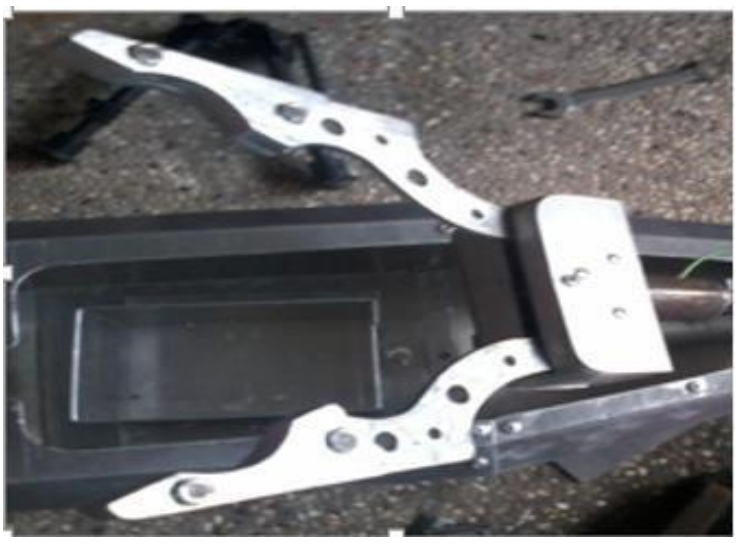

Figure 18. Gripper when opening

When the gripper unit is open, as in Figure 21. When the gripper opens maximally the gripper jaw will open at $200 \mathrm{~mm}$ and the gripper dimension will also change to a length of $220 \mathrm{~mm}$ and the width to $250 \mathrm{~mm}$. When the worm gear moves clockwise it will move the gear towards the outside so that it will open the 
gripper jaw and open position, because the

gripper jaw has been tied into a unit with gear.

\subsubsection{Gripper Elevation Manager}

The elevation regulator is used to adjust the gripper position according to the position of the object to be lifted or moved, this elevation regulator is designed using a servo motor so that it can be controlled with a microcontroller.

As shown in Figures 19 to 20

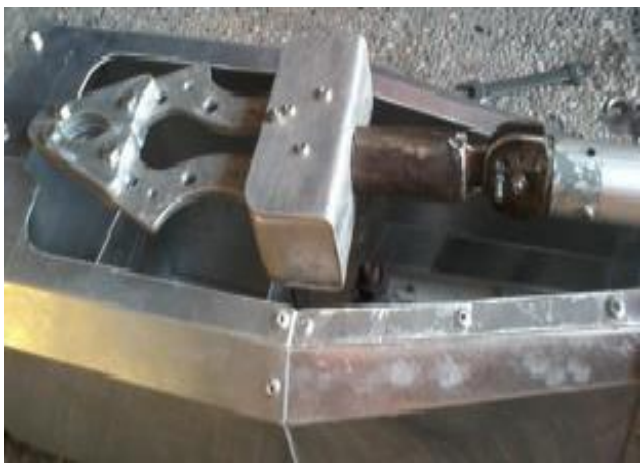

Figure 19. Stick position 180 degrees

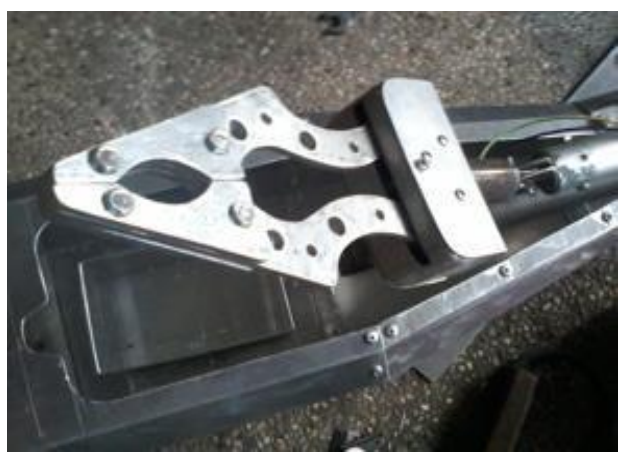

Figure 20. Stick 45 degree position

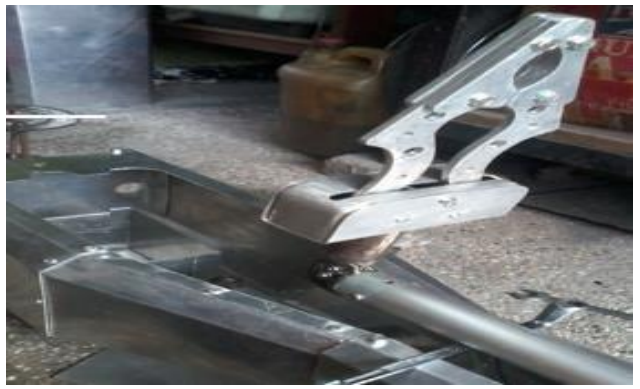

Figure 21. Stick position 90 degrees

\section{CONCLUSION}

a. The force $(F)$ that works when lifting or folding the stick manipulator is $36.75 \mathrm{Kgf}$ while the torque moment is $54.84 \mathrm{~N} . \mathrm{m}$ and the power needed by the drive motor is $5.825 \mathrm{~W}$.

b. The maximum load on the gripper is $1200 \mathrm{~g}$, and the gripping force that occurs is $16.33 \mathrm{~N}$, while the maximum gripping force on the gripper is $19.198 \mathrm{~N}$.

c. All drives use a motor with $12 \mathrm{~V}$ voltage

d. Based on the results of testing and experiments on the actual objects in the field, stick manipulators are more robust and strong and precise in placing explosives on objects and in taking and moving other dangerous items. Can be operated in various positions, namely standing, sitting, or lying down according to the circumstances of the place and the level of danger.

\section{REFERENCE}

Neil Sclater (2011) Mechinisms and mechanical devices sourcebook Fifth Edition, Mc Grow-Hill

Sularso, Kiyokatsu Suga (1991). Dasar Perencanaan dan Pemilihan Elemen Mesin. Jakarta: PT. Pradnya Paramita.

R S Khurmi, J K Gupta (1984) Mechanical Engineering ( Conventional and Objective Type) S. Chand Publising

Binsar Hariandja Ph.D,(1996) Mekanika Teknik. Statika dalam Analisis Struktur Berbentuk Rangka, Erlangga, Jakarta

Jhon Dwight, (1999) Aluminium Design and Contruction

Dr. James L. Meriam, Mekanika Teknik Statika Jilid 1 Prenhall Indo (1998) 
Endra Pitowarno, (2006). Konfigurasi Robot

jaya.ac.id (1995)

Reni Musdaifah 2014, Kumpulan Rumus

Lengkap Fisika, Dunia Cerdas

Latihan lempar granat di Puslatpur Marinir

Purboyo, Malang

Paket Instruksi lempar granat Puslatdiksarmil, Kodiklatal

Buku panduan lempar granat Puslatdiksarmil, Kodiklatal 